\title{
Short communication: Effect of dietary manipulation of crude protein content and nonfibrous-to-fibrous-carbohydrate ratio on energy balance in early-lactation dairy cows ${ }^{1}$
}

\author{
S. J. Whelan, ${ }^{*}$ F. J. Mulligan, $\dagger^{2}$ V. Gath, $\dagger$ B. Flynn, ${ }^{*}$ and K. M. Pierce* \\ *School of Agriculture and Food Science, University College Dublin, Lyons Research Farm, Newcastle, Dublin, Ireland \\ †School of Veterinary Medicine, University College Dublin, Belfield, Dublin 4, Ireland
}

\section{ABSTRACT}

Disparities between nutrient intake and demand often result in a state of negative energy balance (EB) in the early-lactation dairy cow. Reducing dietary crude protein $(\mathrm{CP})$ content and providing glucogenic nutrients may overcome this issue. This study evaluates whether or not offering a diet lower in $\mathrm{CP}$ and higher in nonfiber carbohydrates (LP-NFC) can improve EB and the metabolic status of the early-lactation dairy cow compared with a diet higher in $\mathrm{CP}$ and fibrous carbohydrates (HP-FC). Twenty Holstein-Friesian dairy cows were assigned to 1 of 2 dietary treatments in a randomized block design. Diets were isoenergetic (6.57 MJ of net energy for lactation) and formulated to contain $15 \% \mathrm{CP}$ and $6 \%$ starch (HP-FC), or $12 \% \mathrm{CP}$ and $28 \%$ starch (LP-NFC) and were offered for the first $63 \mathrm{~d}$ of lactation. Intake and milk yield were determined daily, whereas milk and blood samples, weights, and body condition scores were collected weekly. Intakes (mean \pm standard errors of the mean, SEM) of dry matter (17.4 $\pm 0.6 \mathrm{~kg} / \mathrm{d})$ and energy $(113.0 \pm 4.6 \mathrm{MJ}$ of net energy for lactation) were not different between treatments. However, the HP-FC group had a higher milk yield (31.8 vs. $28.9 \pm 1.4 \mathrm{~kg} / \mathrm{d})$ and a lower EB compared with the LP-NFC group. Blood urea $\mathrm{N}$ concentration (3.5 vs. $1.8 \pm 0.2 \mathrm{mmol} / \mathrm{L})$ was higher, whereas bilirubin (6.0 vs. $6.7 \pm 0.2 \mathrm{mmol} / \mathrm{L})$ and $\beta$-hydroxybutyrate concentrations ( 0.7 vs. $0.8 \pm 0.05 \mathrm{mmol} / \mathrm{L})$ were lower in the HP-FC group compared with the LP-NFC group. These data suggest that EB can be improved during early lactation through the manipulation of milk output by offering a lower CP, higher NFC diet.

Key words: early lactation, energy balance, dairy cow, carbohydrate

\footnotetext{
Received September 3, 2013.

Accepted July 24, 2014.

${ }^{1}$ Funding for this research was provided under the National Development Plan, through the Research Stimulus Fund, administered by the Department of Agriculture, Fisheries \& Food, Ireland \#RSF

${ }^{2}$ Corresponding author: finbar.mulligan@ucd.ie
} 07536 .

\section{Short Communication}

Increases in the genetic potential for milk production have created technical challenges for nutritionists and metabolic challenges for the early-lactation dairy cow. In particular, disparities between energy intake and that required for production can result in a state of negative energy balance (EB) and a metabolic status that predisposes the cow to reduced reproductive performance and clinical and subclinical production diseases cumulating in reduced profitability at the farm level (McArt et al., 2013). Restricting milk production through reducing dietary $\mathrm{CP}$ supply may be an effective method of improving EB in early-lactation dairy cows (McCormick et al., 2001; Law et al., 2009). However, these effects are inconsistent in the literature, with some reports showing improved EB (Ørskov et al., 1987) and others showing no effect (Chapa et al., 2001; Law et al., 2009). Improvements in EB and metabolic status of the dairy cow are also possible through altering the ratio of fibrous carbohydrates (FC) to NFC, creating diets that are either lipogenic or glucogenic. Previously, van Knegsel et al. (2007) reported a lower milk fat yield $(0.24 \mathrm{~kg} / \mathrm{d})$ and improved daily EB by 56 $\mathrm{kJ} / \mathrm{kg}^{0.75}$ for the glucogenic-type diets.

In the literature, the effect of manipulating dietary $\mathrm{CP}$ concentration on EB has been well documented (Chapa et al., 2001; Law et al., 2009). Similarly, the balance of FC and NFC has been studied for effects on EB (van Knegsel et al., 2007). However, with the exception of Broderick (2003), who evaluated the effect of dietary $\mathrm{CP}$ and energy content in mid-lactation cows (126 DIM), limited information exists on the simultaneous application of energy type and $\mathrm{CP}$ content to improve EB in the early-lactation cow. This experiment aimed to evaluate the effects of offering diets lower in $\mathrm{CP}$ and higher in NFC on milk production, EB, and metabolic profile in the early-lactation dairy cow.

The procedures described in this manuscript were conducted under experimental license from the Irish Department of Health and Children in accordance with the Cruelty to Animals Act 1876 and the European 
Table 2. Effect of dietary treatment on nutrient intake, milk production, and milk composition

\begin{tabular}{lcccc}
\hline Item & HP-FC TMR & LP-NFC TMR & SEM & $P$-value \\
\hline Intake $(\mathrm{kg} / \mathrm{d})$ & & & & \\
DM & 17.0 & 17.6 & 0.56 & 0.35 \\
Output (kg/d, unless otherwise stated) & 31.3 & 29.6 & 0.60 & $<0.01$ \\
Milk & 1.29 & 1.19 & 0.05 & 0.08 \\
Fat & 0.92 & 0.85 & 0.02 & $<0.01$ \\
Protein & 0.70 & 0.64 & 0.02 & $<0.01$ \\
Casein & & & \\
Milk composition (\%, unless otherwise stated) & 4.01 & 3.88 & 0.15 & 0.39 \\
Fat & 2.92 & 2.93 & 0.06 & 0.89 \\
Protein & 2.21 & 2.21 & 0.03 & 0.98 \\
Casein & 3.57 & 1.40 & 0.36 & $<0.01$ \\
Urea N (mmol/L) & & &
\end{tabular}

tendency toward significance assumed at $0.05<P<$ 0.10 .

For all early-postpartum nutritional strategies, optimizing DMI is of paramount importance. In this study, no effect of diet on DMI $(P=0.35$; Table 2$)$ was detected; thus, intake of starch was higher for animals offered LP-NFC $(P<0.01)$, whereas CP $(P<0.01)$ and $\operatorname{NDF}(P<0.01)$ intake was higher for those offered HP-FC. However, animals did not consume their $20 \mathrm{~kg}$ of DM allocation at any stage during the 9-wk period and, therefore, the quantity of nutrients ingested was not sufficient to meet production requirements. For example, dietary MP supply was lower than that required for maintenance and production, suggesting that a portion of the AA required for milk production was derived from the mobilization of body tissue. Bauman and Elliot (1983) suggested that the early-lactation dairy cow could mobilize between 5 and $13 \mathrm{~kg}$ of body protein without adverse effects on cow health. Our deficit was within the range of 0.2 to $0.3 \mathrm{~kg} / \mathrm{d}$ that O'Mara (1996) suggested to be tolerable during the first month of lactation using the methodology of Jarrige (1989). That said, $\mathrm{N}$ intakes in our experiment were within the range of those reported in Law et al. (2009) for diets of a similar CP content (11.4 vs. 14.4\%). However, in the study of Law et al. (2009), animals offered the lower CP diet also had a lower DMI $(-1.5 \mathrm{~kg} / \mathrm{d})$ and this may have partly attributed to the large difference in $\mathrm{MY}(+6.4 \mathrm{~kg} / \mathrm{d})$ between the high- and low-CP groups. In the current study, reducing dietary CP to limit milk production resulted in a $1.7 \mathrm{~kg} / \mathrm{d}$ reduction in $\mathrm{MY}$, consistent with the predicted response of MY to reduced CP intake by the NRC (2001). Similarly, milk protein yield was reduced where LP-NFC diets were offered, consistent with the reduction in MY and observations of Law et al. (2009). Milk fat, the most energetically demanding component in milk (Tyrrell and Reid, 1965), was also lower in yield where animals were offered HP-FC compared with those offered LP-
NFC $(P=0.08)$. Thus, the difference observed in EB $\left(-21.8\right.$ vs. $-9.6 \mathrm{MJ} \mathrm{NE}_{\mathrm{L}} / \mathrm{d}$ for HP-FC vs. LP-NFC, respectively; $P=0.01$ ) during this study can be attributed to differences in milk fat yield as well as the other energy-demanding components of milk production: milk protein and lactose.

With the exception of urea, milk composition was unaffected by dietary treatment, suggesting that differences in milk constituent yield observed in this study were as a direct result of the increased MY (Table 2). Urea $\mathrm{N}$ equilibrates in body fluid and concentrations in the milk reflect those in the blood (Gustafsson and Palmquist, 1993). In the current study, higher concentrations of urea $\mathrm{N}$ in blood and milk were likely a result of the increase in rumen $\mathrm{NH}_{3}-\mathrm{N}$ (7.10 vs. $4.24 \pm$ $0.96 \mathrm{mmol} / \mathrm{L}$ for HP-FC vs. LP-NFC, respectively; $P$ $<0.01$ ) from animals offered HP-FC (Table 3). Lowering blood and milk urea $\mathrm{N}$ concentrations is related to reduced urine N excretion (Kauffman and St-Pierre, 2001) and improved reproductive performance in the dairy cow (Butler et al., 1996).

Overall, the differences in EB observed in this experiment were small, with total days in negative EB of 40 and $37 \mathrm{~d}$ for HP-FC and LP-NFC, respectively $(P=0.84$; Figure 1). Similarly, the extent of BCS loss was less than 0.5 units and was, therefore, unlikely to cause a significant metabolic challenge or reduction in reproductive performance in the dairy cow (Buckley et al., 2003; Mulligan et al., 2006). Although EB was more positive for animals offered LP-NFC, serum BHBA concentration was also higher for that treatment (Table 3 ). This may be a result of increased rumen fermentation of starch to butyrate (Reynolds, 2006), reflected by higher BHBA (11.19 vs. $7.79 \pm 0.55 \mathrm{mmol} / \mathrm{L} ; P<$ 0.01 ) combined with reduced mammary gland uptake of BHBA for de novo synthesis of milk fat (Lemosquet et al., 2010) for animals offered LP-NFC. That said, concentrations of BHBA and NEFA observed in our study were below those reported in Mills et al. (1986) for cows 
Table 3. Effect of dietary treatment on energy balance, BCS, rumen fermentation, and selected blood metabolites

\begin{tabular}{lcccc}
\hline Item $^{1}$ & HP-FC TMR & LP-NFC TMR & SEM & $P$-value \\
\hline NE intake (MJ/d) & 109.2 & 116.7 & 4.60 & 0.12 \\
Energy output $^{3}(\mathrm{MJ} / \mathrm{d})$ & 138.5 & 128.9 & 5.56 & 0.03 \\
Energy balance $(\mathrm{MJ} / \mathrm{d})^{\text {BCS }}$ & -21.8 & -9.6 & 4.02 & 0.01 \\
Change in BCS & 2.77 & 2.80 & 0.11 & 0.47 \\
Weight & -0.20 & -0.06 & 0.11 & 0.36 \\
Blood metabolite (mmol/L, unless otherwise stated) & 605 & 587 & 30 & 0.54 \\
Urea N & & & & \\
GGT (IU/L) & 3.52 & 1.76 & 0.21 & $<0.01$ \\
GLDH (IU/L) & 15.01 & 18.90 & 2.29 & 0.11 \\
Glucose & 14.16 & 16.01 & 2.71 & 0.37 \\
Bilirubin & 3.19 & 3.11 & 0.08 & 0.36 \\
NEFA & 6.02 & 6.69 & 0.24 & 0.01 \\
BHBA & 0.40 & 0.36 & 0.07 & 0.54 \\
\end{tabular}

${ }^{1} \mathrm{NE}=$ net energy; BCS = average BCS for the duration of the trial on a scale of 1 to 5 in 0.25 increments (Edmonson et al., 1989); GGT $=\gamma$-glutamyl transferase; GLDH $=$ glutamate dehydrogenase.

${ }^{2} \mathrm{HP}-\mathrm{FC}$ TMR $=$ high-CP, low-NFC TMR; LP-NFC TMR = low-CP, high-NFC TMR.

${ }^{3}$ Energy output was calculated as $\mathrm{NE}_{\mathrm{M}}+\mathrm{NE}_{\mathrm{L}}$, where $\mathrm{NE}_{\mathrm{M}}=0.33 \mathrm{MJ} \times$ weight ${ }^{0.75}(\mathrm{NRC}, 2001)$.

confirmed with ketosis $(4.1$ and $0.81 \mathrm{mmol} / \mathrm{L}$ for BHBA and NEFA, respectively), reflecting the low levels of body tissue mobilization observed during the current study. Similarly, bilirubin, although higher for animals offered the LP-NFC treatment $(P=0.01)$, was within the normal range $(0.7$ to $14 \mathrm{mmol} / \mathrm{L}$ ) reported for dairy cows (Boyd, 1984). Additionally, the concentrations of the liver enzymes glutamate dehydrogenase $(>25 \mathrm{IU} / \mathrm{L})$ and $\gamma$-glutamyl transferase $(>40 \mathrm{IU} / \mathrm{L})$ were below the thresholds indicative of fatty liver (West, 1997). Interestingly, glucose levels were not elevated where animals were offered the LP-NFC diet, despite starch supply being almost $4 \mathrm{~kg} / \mathrm{d}$ higher and milk lactose yield be- ing $0.09 \mathrm{~kg} / \mathrm{d}$ lower. However, glucose levels are tightly regulated in the body and the provision of extra starch in our experiment may have encouraged glucose uptake by peripheral tissue via increased insulin (van Knegsel et al., 2007; Garnsworthy et al., 2008). The mammary gland also displays flexibility in its choice of nutrients for the synthesis of lactose, reducing its requirement for glucose. Bequette et al. (2006) demonstrated that 46 to $86 \%$ of galactose was synthesized from non-glucose sources, such as NEAA, BHBA, and acetate. In the current experiment, glucose levels may have been maintained through a combination of increased uptake by peripheral tissues in animals offered the LP-NFC TMR

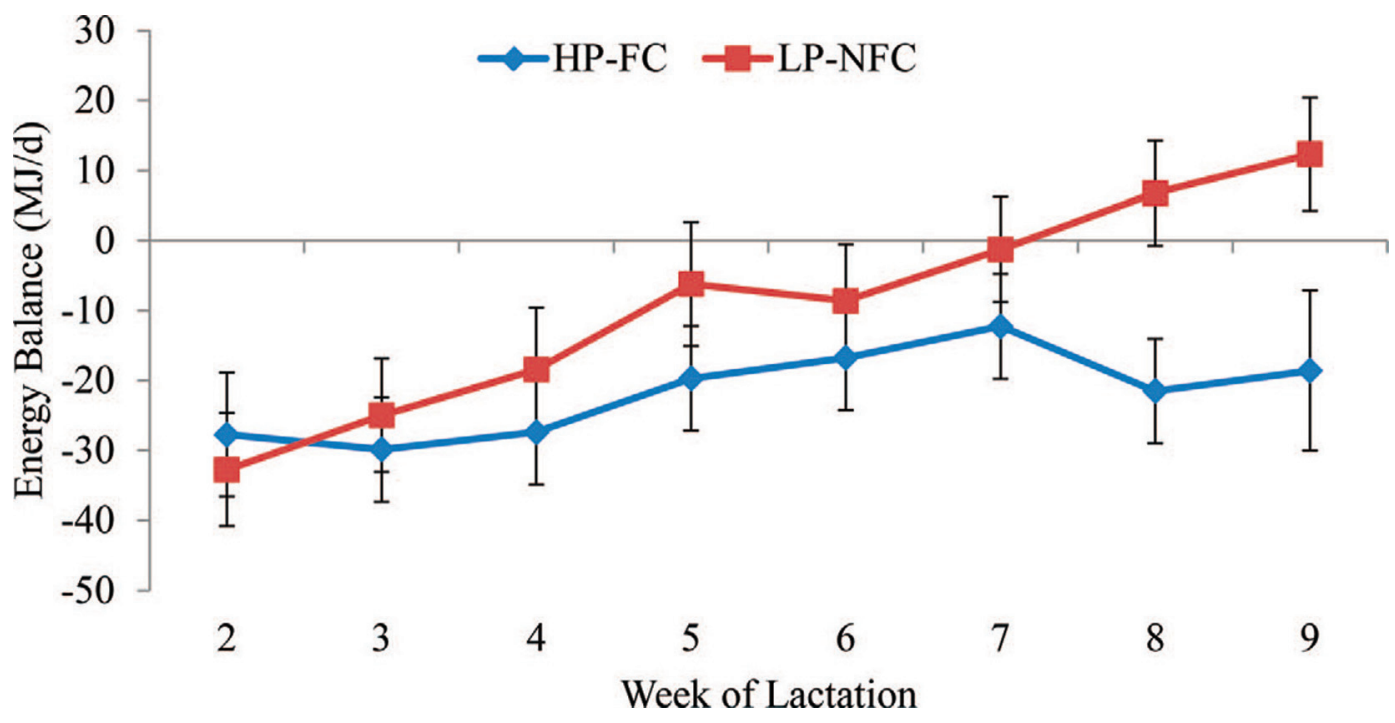

Figure 1. Effect of dietary treatment on energy balance $(\mathrm{MJ} / \mathrm{d})$ over the first 9 wk of lactation. The error bars represent the SEM for each week's LSM. Color version available in the online PDF. 
and reduced mammary uptake in animals offered the HP-FC TMR.

The results of this experiment indicate that altering the ratio of dietary fibrous carbohydrates to NFC and $\mathrm{CP}$ content improves EB during early lactation associated with a reduction in MY. Further research is required in this area to determine the effects of such dietary strategies on fertility parameters and lifetime production capabilities of the dairy cow. This will ultimately aid the producer in determining the feasibility of applying a postpartum nutritional strategy such as that reported herein.

\section{REFERENCES}

Bauman, D. E., and J. M. Elliot. 1983. Control of nutrient partitioning in lactating ruminants. Pages $437-468$ in Biochemistry of Lactation. T. B. Mepham, ed. Elsevier Science Publishers, Amsterdam, the Netherlands.

Bequette, B. J., N. E. Sunny, S. W. El-Kadi, and S. L. Owens. 2006 Application of stable isotopes and mass isotopomer distribution analysis to the study of intermediary metabolism of nutrients. J. Anim. Sci. 84(E. Suppl.):E50-E59.

Boyd, J. W. 1984. The interpretation of serum biochemistry test results in domestic animals. Vet. Clin. Pathol. 13:7-14.

Broderick, G. A. 2003. Effects of varying dietary protein and energy levels on the production of lactating dairy cows. J. Dairy Sci. 86:1370-1381.

Buckley, F., K. O'Sullivan, J. F. Mee, R. D. Evans, and P. Dillon. 2003. Relationships among milk yield, body condition, cow weight, and reproduction in spring-calved Holstein-Friesians. J. Dairy Sci. 86:2308-2319.

Butler, W. R., J. J. Calaman, and S. W. Beam. 1996. Plasma and milk urea nitrogen in relation to pregnancy rate in lactating dairy cattle. J. Anim. Sci. 74:858-865.

Chapa, A. M., M. E. McCormick, J. M. Fernandez, D. D. French, J. D. Ward, and J. F. Beatty. 2001. Supplemental dietary protein for grazing dairy cows: Reproduction, condition loss, plasma metabolites, and insulin. J. Dairy Sci. 84:908-916.

Department of Health and Children. 2005. S.I. No. 613/2005-European Communities (Amendment of Cruelty to Animals Act 1876) Regulations 2002 and 2005. In Statutory Instruments no. 613 of 2005. Department of Health and Children, Dublin, Ireland.

Edmonson, A. J., I. J. Lean, L. D. Weaver, T. Farver, and G. Webster. 1989. A body condition scoring chart for Holstein dairy cows. J. Dairy Sci. 72:68-78.

Garnsworthy, P. C., A. Lock, G. E. Mann, K. D. Sinclair, and R. Webb. 2008. Nutrition, metabolism, and fertility in dairy cows: 1 . Dietary energy source and ovarian function. J. Dairy Sci. 91:3814-3823.

Gustafsson, A. H., and D. L. Palmquist. 1993. Diurnal variation of rumen ammonia, serum urea, and milk urea in dairy cows at high and low yields. J. Dairy Sci. 76:475-484.

Hart, K. J., P. G. Martin, P. A. Foley, D. A. Kenny, and T. M. Boland. 2009. Effect of sward dry matter digestibility on methane production, ruminal fermentation, and microbial populations of zero-grazed beef cattle. J. Anim. Sci. 87:3342-3350.

Jarrige, R., editor. 1989. Ruminant Nutrition: Recommended Allowances and Feed Tables. John Libbey, London, UK, and Paris, France.

Kauffman, A. J., and N. R. St-Pierre. 2001. The relationship of milk urea nitrogen to urine nitrogen excretion in Holstein and jersey cows. J. Dairy Sci. 84:2284-2294.
Law, R. A., F. J. Young, D. C. Patterson, D. J. Kilpatrick, A. R. G. Wylie, and C. S. Mayne. 2009. Effect of dietary protein content on animal production and blood metabolites of dairy cows during lactation. J. Dairy Sci. 92:1001-1012.

Lemosquet, S., J. Guinard-Flament, G. Raggio, C. Hurtaud, J. van Milgen, and H. Lapierre. 2010. How does increasing protein supply or glucogenic nutrients modify mammary metabolism in lactating dairy cows? Pages 175-186 in Energy and Protein Metabolism and Nutrition. 3rd EAAP Intl. Symp. Energy Protein Metabol. Nutr., Parma, Italy. G. M. Crovetto, ed. Wageningen Academic Publishers, Wageningen, the Netherlands.

McArt, J. A., D. V. Nydam, G. R. Oetzel, T. R. Overton, and P. A. Ospina. 2013. Elevated non-esterified fatty acids and $\beta$-hydroxybutyrate and their association with transition dairy cow performance. Vet. J. 198:560-570.

McCormick, M. E., J. D. Ward, D. D. Redfearn, D. D. French, D. C. Blouin, A. M. Chapa, and J. M. Fernandez. 2001. Supplemental dietary protein for grazing dairy cows: Effect on pasture intake and lactation performance. J. Dairy Sci. 84:896-907.

Mills, S. E., D. C. Beitz, and J. W. Young. 1986. Characterization of metabolic changes during a protocol for inducing lactation ketosis in dairy cows. J. Dairy Sci. 69:352-361.

Mulligan, F. J., L. O'Grady, D. A. Rice, and M. L. Doherty. 2006. A herd health approach to dairy cow nutrition and production diseases of the transition cow. Anim. Reprod. Sci. 96:331-353.

NRC. 2001. Nutrient Requirements of Dairy Cattle. 7th rev. ed. Natl. Acad. Sci., Washington, DC.

NRC. 2012. Nutrient Requirements of Dairy Cattle. 1.1.9 ed. NRC, Board on Agriculture and Natural Resources, Washington, DC.

O'Mara, F. P. 1996. A Net Energy System for Cattle and Sheep. University College Dublin, Dublin, Ireland.

Ørskov, E. R., G. W. Reid, and C. A. G. Tait. 1987. Effect of fish meal on the mobilization of body energy in dairy cows. Anim. Prod. $45: 345-348$

Reynolds, C. K. 2006. Production and metabolic effects of site of starch digestion in dairy cattle. Anim. Feed Sci. Technol. 130:78-94.

SAS Institute. 2004. SAS User's Guide. 9.1.2 ed. SAS Institute Inc., Cary, NC.

Tyrrell, H. F., and J. T. Reid. 1965. Prediction of the energy value of cow's milk. J. Dairy Sci. 48:1215-1223.

van Knegsel, A. T. M., H. van den Brand, J. Dijkstra, W. M. van Straalen, R. Jorritsma, S. Tamminga, and B. Kemp. 2007. Effect of glucogenic vs. lipogenic diets on energy balance, blood metabolites, and reproduction in primiparous and multiparous dairy cows in early lactation. J. Dairy Sci. 90:3397-3409.

Weatherburn, M. W. 1967. Phenol-hypochlorite reaction for determination of ammonia. Anal. Chem. 39:971-974.

West, H. J. 1997. Clinical and pathological studies in cattle with hepatic disease. Vet. Res. Commun. 21:169-185.

Whelan, S. J., F. J. Mulligan, J. J. Callan, B. Flynn, and K. M. Pierce. 2013. Effect of forage source and a supplementary methionine hydroxyl analogue on rumen fermentation parameters in lactating dairy cows offered a low crude protein diet. Anim. Feed Sci. Technol. $183: 62-66$.

Whelan, S. J., F. J. Mulligan, B. Flynn, C. McCarney, and K. M. Pierce. 2011. Effect of forage source and a supplementary methionine hydroxy analogue on nitrogen balance in lactating dairy cows offered a low crude protein diet. J. Dairy Sci. 94:5080-5089.

Whelan, S. J., K. M. Pierce, B. Flynn, and F. J. Mulligan. 2012. Effect of supplemental concentrate type on milk production and metabolic status in early-lactation dairy cows grazing perennial ryegrass-based pasture. J. Dairy Sci. 95:4541-4549. 